\title{
Sudden detraining deteriorates swimming training- induced enhancement of short-term and spatial learning memories in mice
}

\author{
You-Mi Kim', Eun-Sang Ji², Sung-Jin Yoon ${ }^{3}$, Jin-Hwan Yoon ${ }^{1, *}$ \\ 'Department of Sports Science, College of Life Science and Nano Technology, Hannam University, Daejeon, Korea \\ 2Department of Sport \& Health Science, College of Natural Science, Sangmyung University, Seoul, Korea \\ ${ }^{3}$ Department of Physical Education, College of Education, Korea University, Seoul, Korea
}

In the present study, we investigated the effect of swimming training and sudden detraining on learning ability and spatial memory capability and on neurogenesis and brain-derived neurotrophic factor (BDNF) expression in the hippocampus of mice. Male ICR mice were randomly assigned into three groups ( $n=15$ in each group): the control group, the swimming training group, and the detraining group. The mice in the swimming training group were made to swim (6 days/week, $60 \mathrm{~min} /$ day) for 8 weeks. The mice in the detraining group were accomplished the same swimming program for 4 weeks and then discontinued exercise for 4 weeks. In the present results, enhanced short-term and spatial learning memories and increased hippocampal neurogenesis and
BDNF expression were observed in the mice of the swimming training group. In contrast, decreased short-term and spatial learning memories were observed in the mice of the swimming detraining group compared to the control level. Hippocampal neurogenesis and BDNF expression were also decreased in the mice of the detraining group near to the control level. Here in this study, we suggest that sudden cessation of exercise training might bring decline of the brain functions.

Keywords: Training, Detraining, Short-term memory, Spatial learning memory, Neurogenesis, Brain-derived neurotrophic factor

\section{INTRODUCTION}

Neurogenesis continues throughout adulthood in a variety of species, including humans (Eriksson et al., 1998; Gould et al., 1999; Kuhn et al., 1996). This new cell birth and neurogenesis occur in the rostral subventricular zone (SVZ) of the lateral ventricles and the subgranular zone (SGZ) of the dentate gyrus (Jin et al., 2001). Neurogenesis is known to play an important role in learning and memory processes of the hippocampus (Shors et al., 2002).

Neurotrophins play crucial roles in the development of central nervous system (CNS), exerting influence on cell survival, differentiation, and cell death (Huang and Reichardt, 2001). Brain-derived neurotrophic factor (BDNF) is a small dimeric protein, and works through its receptor, tyrosine kinase B (Trk-B). BDNF modulates neural growth and survival, and BDNF is implicated in learning and memory processes; therefore, dysfunction in BDNF is accompanied by cognitive deficits (Gomez-Pinilla and Vaynman, 2005). BDNF enhances hippocampal-dependent memory and long-term potentiation, a form of synaptic plasticity, via Trk-B (Minichiello, 2009). A high level of BDNF is concentrated in the hippocampus, and BDNF is selectively increased following activity-dependent learning and memory tasks (Zimmerberg et al., 2009).

Exercise training is also known to improve brain functions such as short-term and spatial learning memories and cognitive function, increase neurogenesis and neurotrophic factors expression, and enhances long-term potentiation (Kim et al., 2007; Kramer and Erickson, 2007; Lee et al., 2006; O'Callaghan et al., 2007). The exercise-induced neurogenesis is known to be coincided with increased expression of BDNF (Farmer et al., 2004). In particular,
${ }^{*}$ Corresponding author: Jin-Hwan Yoon

Department of Sports Science, College of Life Science and Nano Technology, Hannam University, 70 Hannam-ro, Daedeok-gu, Daejeon 306-791, Korea Tel.: +82-42-629-7990, Fax: +82-42-629-8402, E-mail: yoonih@hannam.ac.kr Received: March 5, 2013/ Revised: March 12, 2013/ Accepted: March 30, 2013
This is an Open Access article distributed under the terms of the Creative Commons Attribution Non-Commercial License (http://creativecommons.org/licenses/by-nc/3.0/) which permits unrestricted non-commercial use, distribution, and reproduction in any medium, provided the original work is properly cited. 
swimming is known to induce various changes in the functions of the rat's brain (Senturk et al., 2000). It was demonstrated that swimming increases neurogenesis in the hippocampal dentate gyrus of rats (Lee et al., 2006; Ra et al., 2002). Radak et al. (2006) reported that regular exercise training improves memory function through increment of expressions of BDNF and nerve growth factor (NGF) in rat brain.

Detraining has been defined as the 'cessation' of training-induced adaptations (Mujika and Padilla, 2000). Detraining has been reported to exert negative effects on cardiovascular adaptation (Gamelin et al., 2007), muscle function (Gondin et al., 2006), and energy metabolism (Mujika and Padilla, 2001; Slentz et al., 2007).

Although previous studies have documented that swimming exercise training increases neurogenesis and improves memory function (Ra et al., 2002; Radak et al., 2006), the effects of detraining of swimming exercise on neurogenesis and memory function are still scarce. In the present study, we investigated the effects of swimming training and sudden detraining on short-term memory, spatial learning memory, and BDNF expression in the hippocampus using mice.

\section{MATERIALS AND METHODS}

\section{Animals and treatments}

Male ICR mice weighing $40 \pm 10 \mathrm{~g}$ ( 6 weeks of age) were used for the experiment. The experimental procedures were performed in accordance with the animal care guidelines of the National Institutes of Health (NIH) and the Korean Academy of Medical Sciences. The mice were housed under the controlled temperature $\left(20 \pm 2^{\circ} \mathrm{C}\right)$ and the lighting $(08: 00-20: 00 \mathrm{~h})$ conditions. Food and water were made available ad libitum. The mice were randomly assigned to each of three groups ( $\mathrm{n}=15$ in each group): the control group, the training group, and detraining group. The animals were lived in the cage $(48 \times 26 \mathrm{~cm})$, and 5 mice were placed per cage. The mice of all groups were injected intraperitoneally with 5-bromo-2'-deoxyuridine (BrdU; $50 \mathrm{mg} / \mathrm{kg}$; Sigma Chemical Co., St. Louis, MO, USA) once a day for 8 weeks. The animals divided into the 3 groups: control group, training group, and detraining group. The animals were sacrificed immediately after behavior tests.

\section{Swimming training and detraining}

The mice in the training group were made to swim for $60 \mathrm{~min}$ per day, 6 days a week during 8 weeks. The mice in the detraining group were accomplished the swimming training for 60 min per day, 6 days a week for 4 weeks, and then discontinued training during next 4 weeks. Water temperature was maintained at $32^{\circ} \mathrm{C}$ during swimming training. The mice in the control group were lived in the cage without swimming training for the same duration.

\section{Step-down avoidance test}

In order to investigate the short-term memory of the mice, the latency time in the step-down avoidance test was determined, as previous described method (Cho et al., 2012; Kim et al., 2012). The mice were trained in a step-down avoidance test on the 8 weeks after starting experiment, and they were tested on $24 \mathrm{~h}$ after training session in the step-down avoidance test. The mice were placed on a $7 \times 25$ platform, at height of $2.5 \mathrm{~cm}$, and allowed to rest on the platform for $2 \mathrm{~min}$. The platform faced a $42 \times 25$ $\mathrm{cm}$ grid of parallel $0.1 \mathrm{~cm}$-caliber stainless steel bars, which were spaced $1 \mathrm{~cm}$ apart. During training session, the animals received $0.5 \mathrm{~mA}$ scramble foot shock for 3 sec immediately upon stepping down. The time staying on the platform until stepping down and placing all four paws on the grid was defined as the latency of the step-down avoidance test. Latencies over 300 sec were counted as $300 \mathrm{sec}$.

\section{Radial-arm maze test}

The spatial learning memory was tested using a radial-arm maze apparatus, as previously described (Cho et al., 2012; Kim et al., 2010). The radial-arm maze apparatus consisted of a central octagonal plate $(30 \mathrm{~cm}$ in diameter) and radiating eight arms (50 $\mathrm{cm}$ in length and $10 \mathrm{~cm}$ in width). A small receptacle filled with water $(3 \mathrm{~cm}$ in diameter and $1 \mathrm{~cm}$ in depth) was located at the end of the arms. The mice were trained three times before the spatial learning test. During the training sessions, the mice was deprived of water for $24 \mathrm{~h}$ and allowed to explore the water for 5 min after finishing each session. On the 8 weeks after starting experiment, the spatial learning memory was determined. The time spent for the seeking of water at the end of the arms was counted. The test was terminated when a mouse found water in all eight arms or over 8 min elapsed. The number of correct choice before the first error was counted, and re-entry into the previously visited arms was counted as the number of error choice.

\section{Tissue preparation}

The mice were sacrificed after the completion of behavior tests. The animals were weighed and anesthetized using Zoletil $50^{\circledR}(10$ $\mathrm{mg} / \mathrm{kg}$, i.p.; Vibac Laboratories, Carros, France). After a complete 
lack of response was observed, the mice were transcardially perfused with $50 \mathrm{mM}$ phosphate-buffered saline (PBS) and fixed with a freshly prepared solution consisting of $4 \%$ paraformaldehyde (PFA) in $100 \mathrm{mM}$ phosphate buffer (PB, pH 7.4). The brains were dissected and post-fixed in the same fixative overnight and transferred into a $30 \%$ sucrose solution for cryoprotection. Serial coronal sections of $40 \mu \mathrm{m}$ thickness were made with a freezing microtome (Leica, Nussloch, Germany).

\section{Immunohistochemistry}

BrdU immunohistochemistry was used for the detection of newly generated cells in the hippocampal dentate gyrus, as the previously described method (Cho et al., 2012; Kim et al., 2012). In brief, the sections were initially permeabilized by incubation in $0.5 \%$ Triton X-100 in PBS for 20 min, then pretreated with 50\% formamide $-2 \times$ standard saline citrate (SSC) at $65^{\circ} \mathrm{C}$ for $2 \mathrm{~h}$, denaturated in $2 \mathrm{~N} \mathrm{HCl}$ at $37^{\circ} \mathrm{C}$ for $30 \mathrm{~min}$, and rinsed twice in 100 $\mathrm{mM}$ sodium borate ( $\mathrm{pH}$ 8.5). Afterwards, the sections were incubated overnight at $4{ }^{\circ} \mathrm{C}$ with $\mathrm{BrdU}$-specific mouse monoclonal antibody (1:600; Roche, Mannheim, Germany). The sections were then washed three times with PBS and incubated for $1 \mathrm{~h}$ with a biotinylated mouse secondary antibody (1:200; Vector Laboratories, Burlingame, CA, USA). The sections were then incubated for another $1 \mathrm{~h}$ with avidin-peroxidase complex (1:100; Vector Laboratories). For visualization, the sections were incubated in $50 \mathrm{mM}$ Tris- $\mathrm{HCl}\left(\mathrm{pH}\right.$ 7.6) containing $0.03 \% \mathrm{H}_{2} \mathrm{O}_{2}, 0.02 \%$ 3,3'-diaminobenzidine (DAB), and $40 \mathrm{mg} / \mathrm{mL}$ nickel chloride (nickel-DAB) for $5 \mathrm{~min}$.

After BrdU-specific staining, we performed counter-staining on the same sections using a mouse anti-neuronal nuclei $(\mathrm{NeuN})$ antibody (1:1,000; Chemicon International, Temecula, CA, USA). The sections were then washed three times with PBS, incubated for $1 \mathrm{~h}$ with a biotinylated anti-mouse secondary antibody, and processed with the VECTASTAIN ${ }^{\circledR}$ ABC Kit (1:100; Vector Laboratories). For staining, the sections were allowed to react with $0.02 \% \mathrm{DAB}$ and $0.03 \% \mathrm{H}_{2} \mathrm{O}_{2}$ in $50 \mathrm{mM}$ Tris- $\mathrm{HCl}(\mathrm{pH}$ 7.6) for 5 min and the sections were finally mounted onto gelatin-coated slides. The slides were air-dried overnight at room temperature, and the coverslips were mounted using Permount ${ }^{\circledR}$ (Fisher Scientific, Fair Lawn, NJ, USA).

\section{Western blot analysis}

BDNF expression in the hippocampus was determined, as the previously described method (Cho et al., 2012; Kim et al., 2010). Tissue samples harvested from the hippocampus were lysed in the protein lysis buffer containing $50 \mathrm{mM}$ Tris-HCI (pH 7.5), 150 $\mathrm{mM} \mathrm{NaCl}, 0.5 \%$ deoxycholic acid, $1 \%$ nonidet-P40 (NP40), $0.1 \%$ sodium dodecyl sulfate (SDS), $1 \mathrm{mM}$ phenylmethylsulfonyl fluoride (PMSF), and $100 \mu \mathrm{g} / \mathrm{mL}$ leupeptin. Protein concentration was measured using a Bio-Rad colorimetric protein assay kit (Bio-Rad, Hercules, CA, USA). Protein of $50 \mu \mathrm{g}$ was separated on SDS-polyacrylamide gels and transferred onto a nitrocellulose membrane (Schleicher \& Schuell GmbH, Dassel, Germany). Rabbit anti-BDNF antibody (1:1,000; Santa Cruz Biotechnology, CA, USA), Horseradish peroxidase-conjugated anti-rabbit antibody for BDNF were used as secondary antibodies. Band detection was performed using as enhanced chemiluminescence (ECL) detection system (Amersham Pharmacia Biotech GmbH, Freiburg, Germany). The final amount of western blot product for BDNF expression was calculated densitometrically using Imaging-Pro ${ }^{\circledR}$ Plus (Media Cybernetics Inc., Silver Spring, MD, USA).

\section{Statistical analysis}

The number of BrdU-positive cells in the hippocampal dentate gyrus were counted hemilaterally using Image-Pro ${ }^{\circledR}$ Plus image analyzer (Media Cybernetics Inc.). The number of BrdU-positive cells in the hippocampal dentate gyrus were expressed as the number of cells per $\mathrm{mm}^{2}$ of the cross sectional area of the granular layer. For the confirmation of the expressions of BDNF, the detected bands were calculated densitometrically using Molecular Analyst $^{\mathrm{TM}}$, version 1.4.1 (Bio-Rad).

All data were analyzed using the statistical software SPSS (version 20.0), and the results were expressed as the mean \pm standard error of the mean (SEM). For the comparison among the groups, one-way ANOVA and Duncan's post-hoc test were performed, and differences were considered statistically significant at $P<0.05$.

\section{RESULTS}

\section{Effect of training and detraining on step-down avoidance test}

The latency in the step-down avoidance test was $141.40 \pm 28.56$ sec in the control group, $213.33 \pm 19.48 \mathrm{sec}$ in the training group, and $68.50 \pm 24.37 \mathrm{sec}$ in the detraining group (Fig. 1). The latency in the training group was significantly increased compared to the control group. However, the mice in the detraining group showed more shortened latency compared to the control group.

\section{Effect of training and detraining on radial-arm maze test}

The time taken to complete eight successful performances was 
$216.33 \pm 11.48 \mathrm{sec}$ in the control group, $165.50 \pm 10.00 \mathrm{sec}$ in the training group, and $281.25 \pm 26.35 \mathrm{sec}$ in the detraining group (Fig. 2A). The number of correct choices to complete eight successful performances was $4.22 \pm 0.28 \mathrm{sec}$ in the control group, $5.38 \pm 0.18 \mathrm{sec}$ in the training group, and $4.88 \pm 0.16 \mathrm{sec}$ in the detraining group (Fig. 2B). The number of error response to complete eight successful performances was $8.56 \pm 0.60 \mathrm{sec}$ in the control group, $6.75 \pm 0.73 \mathrm{sec}$ in the training group, and $11.50 \pm 1.02$ sec in the detraining group (Fig. 2C). Our data demonstrated that the time and error number taken to complete eight successful performances were lower and correct number was higher in the training group compared to the control group. However, the mice in the detraining group showed more time and error number with no change in the correct number compared to the control group.

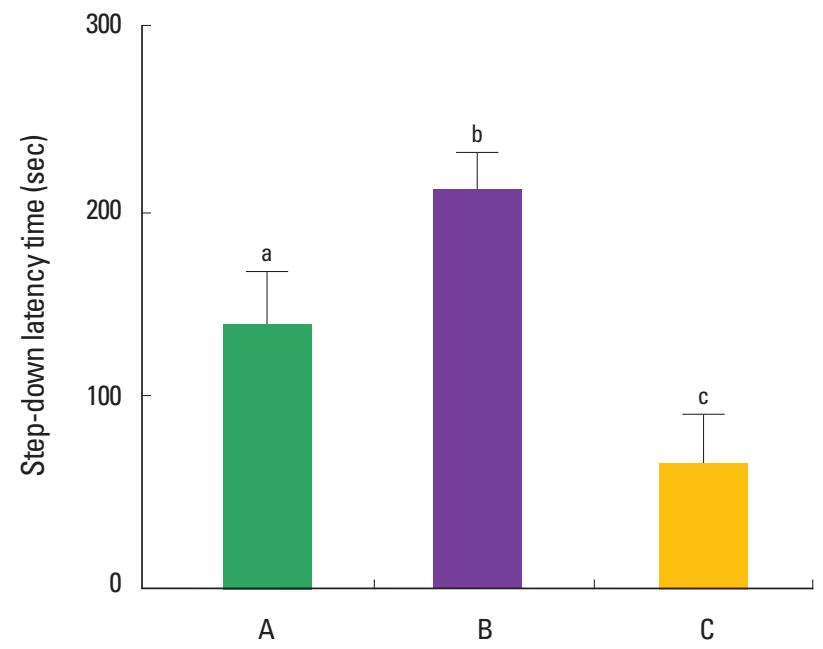

Fig. 1. Effects of the training and detraining on latency in the step-down avoidance test. (A) Control group, (B) training group, (C) detraining group. The data are represented as the mean \pm SEM.

\section{Effect of training and detraining on the hippocampal neurogenesis}

Photomicrographs of BrdU-positive cells are shown in Fig. 3. The number of BrdU-positive cells in the dentate gyrus of the hippocampus was $142.71 \pm 6.78 / \mathrm{mm}^{2}$ in the control group, $242.45 \pm$ $12.85 / \mathrm{mm}^{2}$ in the training group, and $157.29 \pm 7.16 / \mathrm{mm}^{2}$ in the
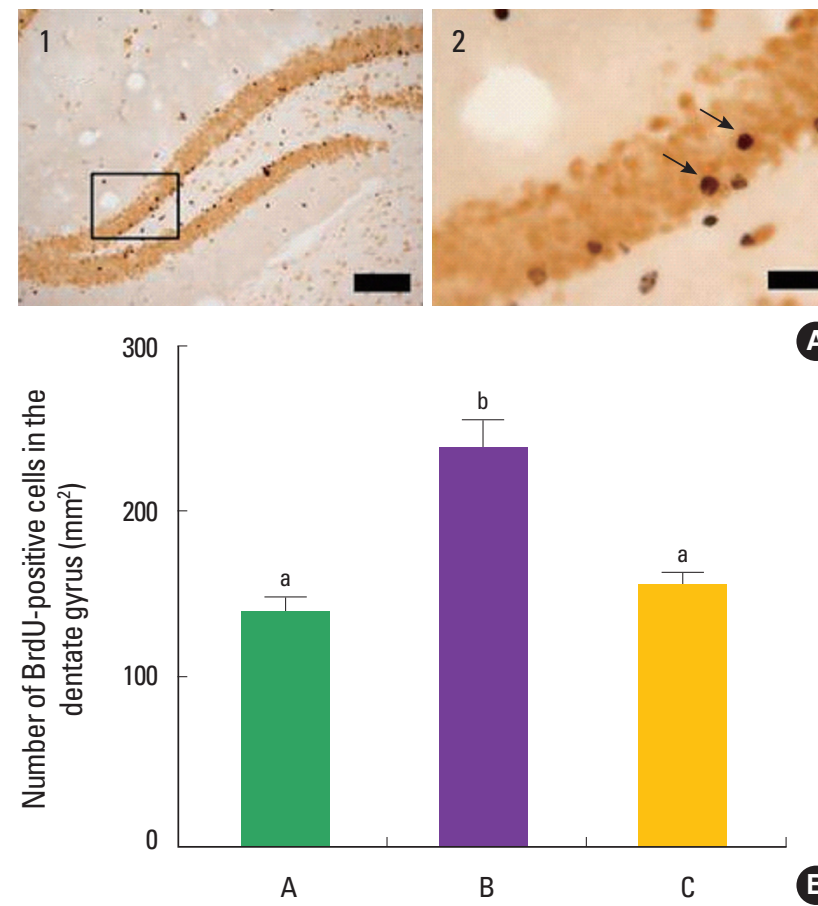

Fig. 3. Effects of the training and detraining on neurogenesis in the hippocampus. (A) Photomicrographs of 5-bromo-2'-deoxyuridine (BrdU)-positive cells. The sections were stained for BrdU (black) and neuronal nuclei (NeuN; brown). The scale bar represents $100 \mu \mathrm{m}$ (1) and $25 \mu \mathrm{m}$. (B) The number of BrdU- positive cells in the dentate gyrus of hippocampus. (A) Control group, (B) training group, (C) detraining group. The data are represented as the mean \pm SEM.
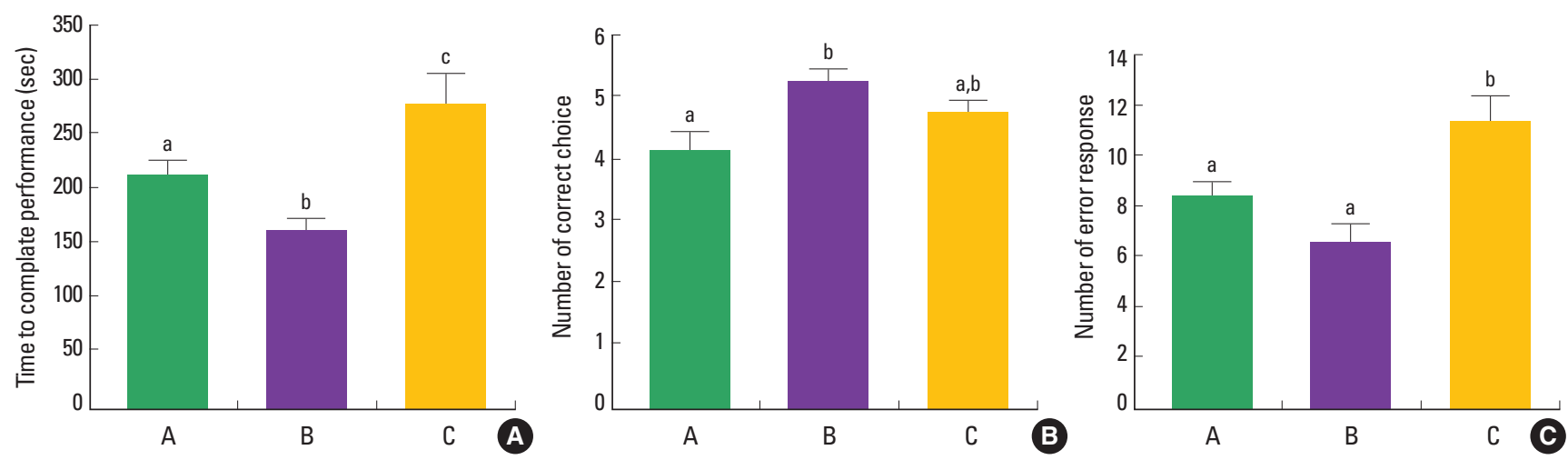

Fig. 2. Effects of the training and detraining on time, correct number, and error number in the radial-arm maze test. (A) The time taken to complete eight successful performances. (B) The number of correct choice to complete eight successful performances. (C) The number of error response to complete eight successful performances. (A) Control group, (B) training group, (C) detraining group. The data are represented as the mean \pm SEM. 


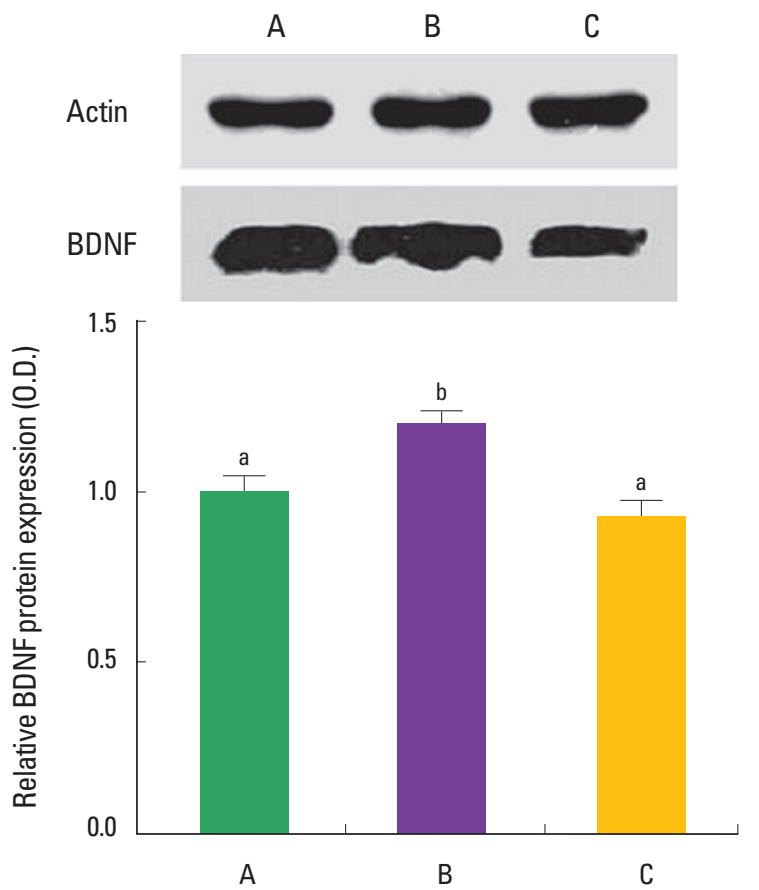

Fig. 4. Effects of the training and detraining on the BDNF expression. Actin was used as internal control. (A) Control group, (B) training group, (C) detraining group. The data are represented as the mean \pm SEM.

detraining group. The present results showed that swimming training increased neurogenesis in the dentate gyrus, and detraining decreased neurogenesis in the dentate gyrus near to the control level.

\section{Effect of training and detraining on the BDNF protein expression}

BDNF expression is presented in Fig. 4. The expression of BDNF in the hippocampus was $1.00 \pm 0.41$ in the control group, $1.19 \pm$ 0.20 in the training group, and $0.93 \pm 0.21$ in the detraining group. The present results showed that swimming training increased BDNF expression in the hippocampus, and detraining decreased BDNF expression in the hippocampus near to the control level.

\section{DISCUSSION}

In the present study, short-term memory was improved by swimming training, and swimming training also increased hippocampal neurogenesis in the mice. Enhancing effect of exercise on hippocampal neurogenesis is well documented, and increment of learning ability and memory function by exercise has been suggested to be mediated through this increment of neurogenesis
(Kim et al., 2007; Lee et al., 2006; Snyder et al., 2005). Swimming also increased cell proliferation in the dentate gyrus of rat hippocampus (Ra et al., 2002). The results of our present study corroborated that swimming training enhanced hippocampal neurogenesis, and this effect of swimming training improved the memory function in mice.

In the present study, BDNF expression was increased in the hippocampus of mice that performed swimming training. Neurotrophins is implicated in neuronal survival, differentiation, connectivity, and plasticity (Huang and Reichardt, 2001; Schinder and Poo, 2000). Exercise is known to increase expressions of a variety of neurotrophic factors, including basic fibroblast growth factor (bFGF), insulin-like growth factor-1 (IGF-1), and BDNF expression (Carro et al., 2001; Gómez-Pinilla and Vaynman, 2005). Of them, BDNF is known to enhance synaptic transmission and neuronal plasticity in the CNS (Schinder and Poo, 2000), resulting in increase in learning ability and memory capability (Mizuno et al., 2000). BDNF enhances hippocampal-dependent memory and long-term potentiation, a form of synaptic plasticity, via Trk-B (Minichiello, 2009). A high level of BDNF is concentrated in the hippocampus, and BDNF is selectively increased following activity-dependent learning and memory tasks (Zimmerberg et al., 2009). Exercise tends to increase the expression of BDNF mRNA in the hippocampus (Johnson et al., 2003; Russo-Neustadt et al., 2000). Exercise-induced BDNF expression is known to enhance not only neurogenesis but also LTP in the hippocampus (Farmer et al., 2004). The results of our present study suggested the correlation of the increment of neurogenesis with enhancement of BDNF expression induced by swimming training in mice.

Unlike positive effects of the training, detraining is defined as the partial or complete loss of training-induced performance adaptation as a consequence of reduction or cessation of training (Gamelin et al., 2007; Gondin et al., 2006; Slentz et al., 2007). Detraining induced decrement in the cognitive function and memory capability (Hansen et al., 2004; Radak et al., 2006). In the present results, number of BrdU-positive cells and expression of BDNF in the detraining group were decreased near to the control levels. However in the detraining group, latency in the step-down avoidance test was lower, and time taken to complete eight successful performances was longer and error number in the radialarm maze test was higher compared to the control group. These results suggest that detraining exerted deteriorating effects on short-term memory and spatial learning memory than un-trained control group. Radak et al. (2006) reported that regular exercise training improved memory function, decreased the level of reac- 
tive oxygen species, and increased the production of BDNF and NGF. On the other hand, the beneficial effects of training were reversible in the brain, since detraining down-regulated the neurotrophin level and memory function.

In the present study, swimming exercise showed enhancing effects on short-term and spatial learning memories through increasing neurogenesis with BDNF expression in the hippocampus. In contrast, detraining showed deteriorating effects on shortterm and spatial learning memories without deleterious effects on neurogenesis and BDNF expression in the hippocampus. This memory deteriorating effect of detraining considered as the temporary event. Based on the present results, we suggest that sudden stopping of exercise may induce transient memory deterioration.

\section{CONFLICT OF INTEREST}

No potential conflict of interest relevant to this article was reported.

\section{ACKNOWLEDGMENTS}

This work was supported by the National Research Foundation of Korea Grant funded by the Korean Government (NRF-2010354-G00040).

\section{REFERENCES}

Carro E, Trejo JL, Busiguina S, Torres-Aleman I. Circulating insulin-like growth factor I mediates the protective effects of physical exercise against brain insults of different etiology and anatomy. J Neurosci 2001;21:5678-5684.

Cho HS, Kim TU, Ko IG, Baek SS, Sim YJ, Kim H. Effect of spatial learning and treadmill exercise on memory ability in mice. J Exer Rehabil 2012;161-172.

Eriksson PS, Perfilieva E, Bjork-Eriksson T, Alborn AM, Nordberg C, Peterson DA, Gage FH. Neurogenesis in the adult human hippocampus. Nat Med 1998;4:1313-1317.

Farmer J, Zhao X, van Praag H, Wodtke K, Gage FH, Christie BR. Effects of voluntary exercise on synaptic plasticity and gene expression in the dentate gyrus of adult male Sprague-Dawley rats in vivo. Neuroscience 2004;124:71-79.

Gamelin FX, Berthoin S, Sayah H, Libersa C, Bosquet L. Effect of training and detraining on heart rate variability in healthy young men. Int J Sports Med 2007;28:564-570.

Gómez-Pinilla F, Vaynman S. A "deficient environment" in prenatal life may compromise systems important for cognitive function by affecting BDNF in the hippocampus. Exp Neurol 2005;192:235-243.

Gondin J, Guette M, Ballay Y, Martin A. Neural and muscular changes to detraining after electrostimulation training. Eur J Appl Physiol 2006; 97:165-173.

Gould E, Tanapat P, Hastings NB, Shors TJ. Neurogenesis in adulthood: a possible role in learning. Trends. Cog Sci 1999;3:186-192.

Hansen AL, Johnsen BH, Sollers JJ 3rd, tenvik K., Thayer J F. Heart rate variability and its relation to prefrontal cognitive function: the effects of training and detraining. Eur J Appl Physiol 2004;93:263-272.

Huang EJ, Reichardt LF. Neurophins: roles in neuronal development and function. Annu Rev Neurosci 2001;24:677-736.

Jin K, Minami M, Lan JQ, Mao XO, Batteur S, Simon RP, Greenberg DA. Neurogenesis in dentate subgranular zone and rostral subventricular zone after focal cerebral ischemia in the rat. Proc Natl Acad Sci U S A 2001;98:4710-4715.

Johnson RA, Rhodes JS, Jeffrey SL, Garland T, Mitchell GS. Hippocampal brain-derived neurotrophic factor but not neurotrophin-3 increases more in mice selected for increased voluntary wheel running. Neuroscience 2003;121:1-7.

Kim BK, Shin MS, Lee HH, Sung YH, Kim H. Swimming alleviates streptozotocin-induced short-term memory impairment in rats. J Exer Rehabil 2012;8:273-284.

Kim H, Lee SH, Kim SS, Yoo JH, Kim CJ. The influence of maternal treadmill running during pregnancy on short-term memory and hippocampal cell survival in rat pups. Int J Dev Neurosci 2007;25:243-249.

Kim SE, Ko IG, Kim BK, Shin MS, Cho S, Kim CJ, Kim SH, Baek SS, Lee EK, Jee YS. Treadmill exercise prevents aging-induced failure of memory through an increase in neurogenesis and suppression of apoptosis in rat hippocampus. Exp Gerontol 2010;45:357-365.

Kramer AF, Erickson KI. Capitalizing on cortical plasticity: influence of physical activity on cognition and brain function. Trends Cogn Sci 2007;11:342-348.

Kuhn HG, Dickinson-Anson H, Gage FH. Neurogenesis in the dentate gyrus of the adult rat: age-related decrease of neuronal progenitor proliferation. J Neurosci 1996;16:2027-2033.

Lee HH, Kim H, Lee JW, Kim YS, Yang HY, Chang HK, Lee TH, Shin MC, Lee MH, Shin MS, Park S, Baek S, Kim CJ. Maternal swimming during pregnancy enhances short-term memory and neurogenesis in the hippocampus of rat pups. Brain Dev 2006;28:147-154.

Minichiello L. TrkB signalling pathways in LTP and learning. Nat Rev Neurosci 2009;10:850-860.

Mizuno M, Yamada K, Olariu A, Nawa H, Nabeshima T. Involvement of brain-derived neurotrophic factor in spatial memory formation and maintenance in a radial arm maze test in rats. J Neurosci 2000;20:7116- 
7121.

Mujika I, Padilla S. Detraining: loss of training-induced physiological and performance adaptations. Part I. Sports Med 2000;30:79-87.

Mujika I, Padilla S. Cardiorespiratory and metabolic characteristics of detraining in humans. Med Sci Sports Exerc 2001;33:413-421.

O'Callaghan RM, Ohle R, Kelly AM. The effects of forced exercise on hippocampal plasticity in the rat: A comparison of LTP, spatial- and nonspatial learning. Behav Brain Res 2007;176:362-366.

Ra SM, Kim H, Jang MH, Shin MC, Lee TH, Lim BV, Kim CJ, Kim EH, Kim KM, Kim SS. Treadmill running and swimming increase cell proliferation in the hippocampal dentate gyrus of rats. Neurosci Lett 2002; 333:123-126.

Radak Z, Toldy A, Szabo Z, Siamilis S, Nyakas C, Silye G, Jakus J, Goto S. The effect of training and detraining on memory, neurotrophins and oxidative stress makers in rat brain. Neurochem Int 2006;49:387-392.

Russo-Neustadt AA, Beard RC, Huang YM, Cotman CW. Physical activity and antidepressant treatment potentiate the expression of specific brain-derived neurotrophic factor transcripts in the rat hippocampus.
Neuroscience 2000;101:305-312.

Schinder AF, Poo M. The neurotrophin hypothesis for synaptic plasticity. Trends Neurosci 2000;23:639-645.

Senturk UK, Aktekin B, Kuru O, Gunduz F, Demir N, Aktekin MR. Effect of long-term swimming exercise on somatosensory evoked potentials in rat. Brain Res 2000;887:199-202.

Shors TJ, Townsend DA, Zhao M, Kozorovitskiy Y, Gould E. Neurogenesis may relate to some but not all types of hippocampal-dependent learning. Hippocampus 2002;12:578-584.

Slentz CA, Houmard JA, Johnson JL, Bateman LA, Tanner CJ, McCartney JS, Duscha BD, Kraus WE. Inactivity, exercise training and detraining, and plasma lipoproteins. STRRIDE: a randomized, controlled study of exercise intensity and amount. J Appl Physiol 2007;103:432-442.

Snyder JS, Hong NS, McDonald RJ, Wojtowicz JM. A role for adult neurogenesis in spatial long-term memory. Neuroscience 2005;130:843-852.

Zimmerberg B, Foote HE, Van Kempen TA. Olfactory association learning and brain-derived neurotrophic factor in an animal model of early deprivation. Dev Psychobiol 2009;51:333-344. 